\title{
PENGEMBANGAN MULTIMEDIA LECTORA INSPIRE UNTUK MENINGKATKAN KEMAMPUAN BERPIKIR KRITIS DALAM MENYELESAIKAN SOAL CERITA BANGUN RUANG
}

\author{
M. Zaenal Muttaqin ${ }^{1}$, Tatag Yuli Eko Siswono ${ }^{2}$, Agung Lukito ${ }^{3}$ \\ ${ }^{1}$ Universitas Negeri Surabaya, Jl. Lidah Wetan, Kota Surabaya, Indonesia \\ mzaenal.18058@mhs.unesa.ac.id
}

\begin{abstract}
This study aims (1) to produce a valid, practical, and effective multimedia lectora inspire on space building materials in grade $\mathrm{V}$ in elementary schools, (2) to describe the improvement of critical thinking skills in resolving class $\mathrm{V}$ building story problems using multimedia lectora inspire. The subjects of this study were fifth-grade students at SDN Wonokusumo VI / 45 Surabaya. This type of research is research and development (R\&D) using the DDDE model namely decide, design, develop, and evaluate. Multimedia Lectora Inspire has passed the validation test from the media aspect reaching a percentage of $82.50 \%$. with a good category and from the material aspect reaches a percentage of $80.64 \%$ with a good category. The media has also gone through practicality tests that reach good categories. Whereas based on the critical thinking test shows that the effectiveness of multimedia learning is effective in improving students' critical thinking. This is based on the results of the implementation of the test field which progressed by $85 \%$ and classical learning completeness by $88.89 \%$ which means a significant influence on critical thinking on student learning using multimedia lectora inspire.
\end{abstract}

Keywords: Multimedia development, Lectora Inspire, Critical Thinking, Geometry Word Problem

\begin{abstract}
Abstrak
Penelitian ini bertujuan (1) menghasilkan multimedia lectora inspire yang valid, praktis, dan efektif pada materi bangun ruang di kelas $\mathrm{V}$ sekolah dasar, (2) mendeskripsikan peningkatan kemampuan berpikir kritis dalam menyelesaikan soal cerita bangun ruang kelas $\mathrm{V}$ dengan menggunakan multimedia lectora inspire. Subjek penelitian ini adalah siswa kelas lima SDN Wonokusumo VI/45 Surabaya. Jenis penelitian ini adalah penelitian dan pengembangan (R\&D) dengan menggunakan model DDDE yaitu decide, design, develop, dan evaluate. Multimedia lectora inspire telah melalui uji validasi dari aspek media mencapai persentase $82.50 \%$. dengan kategori baik dan dari aspek materi mencapai persentase $80.64 \%$ dengan kategori baik. Media juga telah melalui uji kepraktisan yang mencapai kategori baik. Sedangkan berdasarkan tes berpikir kritis menunjukkan bahwa efektivitas pembelajaran multimedia efektif dalam meningkatkan berpikir kritis siswa. Hal ini didasarkan pada hasil implementasi bidang tes yang mengalami kemajuan sebesar 85\% dan ketuntasan belajar klasikal sebesar $88.89 \%$ yang berarti pengaruh signifikan terhadap berpikir kritis pada pembelajaran siswa menggunakan multimedia lectora inspire.
\end{abstract}

Kata kunci: Pengembangan Multimedia, Lectora Inspire, Berpikir Kritis, Soal Cerita Bangun Ruang

\section{PENDAHULUAN}

Beberapa bulan terakhir, adanya covid-19 memberikan dampak yang begitu luas di segala bidang kehidupan. Tak terkecuali dalam bidang pendidikan, pembelajaran tidak dapat dilakukan secara langsung, sehingga memungkinkan pembelajaran jarak jauh yaitu secara daring, akibatnya dibutuhkan media yang sesuai dengan tujuan dapat membantu siswa dalam memahami materi pelajaran. Khususnya dalam menyelesaikan soal cerita matematika pada materi bangun ruang kelas V. Kemampuan berpikir kritis siswa dalam menyelesaikan soal cerita cenderung masih rendah yang di tandai dengan nilai siswa masih di bawah KKM, daya penalaran, analisa dalam memecahkan masalah yang ada pada soal cerita matematika masih rendah. 
Facione (1992) yang menyatakan bahwa berpikir kritis meliputi kemampuan menganalisis, menarik kesimpulan, melakukan interpretasi, penjelasan, pengaturan diri, ingin tahu, sistematis, bijaksana mencari kebenaran, dan percaya diri terhadap proses berpikir dalam memecahkan masalah. Sedangkan Siswono (2008) menyatakan bahwa berpikir kritis merupakan berpikir yang melibatkan menguji, menghubungkan dan mengevaluasi semua aspek sebuah situasi atau masalah, termasuk di dalamnya adalah mengumpulkan, mengorganisasikan, mengingat dan menganalisis informasi. Berdasarkan pernyataan ini dapat dilihat bahwa kemampuan berpikir kritis merupakan suatu proses berpikir untuk memecahkan masalah dengan cara menganalis, menginterpretasi, serta menarik kesimpulan dari informasi yang diperoleh.

Salah satu cara yang dapat dilakukan oleh guru untuk mengetahui bagaimana kemampuan berpikir kritis siswa adalah ketika siswa melakukan pemecahan masalah matematika. Haryani (2012), mengemukakan bahwa dalam pembelajaran matematika siswa yang terbiasa menyelesaikan masalah matematika akan cenderung berpikir kritis. Salah satu kegiatan pemecahan masalah yang dilakukan adalah menyelesaikan soal cerita matematika. Pemecahan masalah dalam suatu soal cerita matematika merupakan suatu proses yang berisi langkah-langkah yang benar dan logis untuk mendapatkan penyelesaian (Jonassen, 2004). Soal cerita merupakan permasalahan yang dinyatakan dalam bentuk kalimat bermakna dan mudah dipahami (Wahyudin, 2016). Soal cerita dapat disajikan dalam bentuk lisan maupun tulisan, soal cerita yang berbentuk tulisan berupa sebuah kalimat yang mengilustrasikan kegiatan kontekstual dalam kehidupan sehari-hari (Priyanto, 2015).

Pengamatan yang telah dilakukan peneliti kepada guru kelas di SDN Wonokusumo VI/45 Surabaya, didapatkan hasil observasi yaitu: (1) belum ada media pembelajaran yang digunakan pada kegiatan pembelajaran jarak jauh khususnya materi bangun ruang; (2) guru hanya terpaku pada buku paket matematika dari sekolah (3) guru hanya memberikan latihan soal secara daring, tanpa memberikan penjelasan terlebih dahulu pada siswa; dan (4) kemampuan berpikir kritis siswa dalam menyelesaikan soal cerita bangun ruang masih rendah. Maka dari itu, media yang digunakan harus disediakan agar dapat menghasilkan tujuan pembelajaran yang ingin dicapai, salah satu media yang dapat digunakan dalam pembelajaran jarak jauh adalah multimedia.

Menurut Hofstetter (2001) dalam Munir, multimedia adalah penggunaan komputer untuk menyajikan dan menggabungkan teks, suara, gambar, animasi dan video dengan alat bantu (tool) dan koneksi (link) sehingga pengguna dapat melakukan navigasi, berinteraksi, berkarya dan berkomunikasi. Sedangkan Multimedia pembelajaran di artikan sebagai perpaduan antara teks, grafik, gambar, suara, animasi, dan video untuk menyampaikan pesan kepada siswa dalam proses pembelajaran. Di masa pandemi covid-19 yang dalam prosesnya yaitu pembelajaran jarak jauh penggunaan multimedia mudah didistribusikan secara online. Penggunaan media modern diharapkan dapat membangkitkan minat dan motivasi siswa untuk dapat memahami dan memecahkan masalah tentang soal cerita matematika serta melatih keterampilan berpikir kritis siswa. 
Terdapat banyak software multimedia pembelajaran seperti macro media flash, articulate storyline, lectora inspire, powtoon, whiteboard fi, microsoft power point, microsoft sway dan masih banyak lagi. Dari beberapa macam software multimedia pembelajaran, lectora inspire memiliki keunggulan jika di bandingkan dengan software lainnya. Keunggulan tersebut dijelaskan oleh Mas'ud (2004) yaitu: (1) memberikan fitur yang memudahkan pengguna pemula untuk membuat multimedia pembelajaran; (2) dapat digunakan untuk membuat website e-learning dan presentasi; (3) menyediakan media library dan template yang cukup lengkap, misalnya gambar bangun datar dan ruang matematika, serta menyediakan macam-macam format penulisan soal; (4) hasil multimedia dapat dipublikasikan ke dalam format CD-ROM, HTML, single file executable (exe), dan e-learning.

Mas'ud (2004) mengemukakan bahwa lectora inspire merupakan sebuah perangkat lunak authoring tool untuk pengembangan konten e-learning yang dikembangkan oleh Trivantis Corporation. Lectora inspire mampu membuat multimedia dengan cepat dan sederhana. Pendirinya adalah Timothy D. Loudermilk di Cincinnati, Ohio, Amerika pada tahun 1999. Software Lectora Inspire dapat peroleh pada perusahaan Trivantis atau dengan mengunjungi alamat https://www.trivantis.com/. Hingga tulisan ini disusun versi terbaru yang diluncurkan adalah Lectora Inspire v18.2.

Adapun keterkaitan antara penggunaan multimedia lectora inspire dengan kemampuan berpikir kritis dalam menyelsaikan soal cerita bangun ruang antara lain: (1) dengan multimedia dapat mengubah pembahaman yang abstrak menjadi lebih konkret karena terdapat gambar dan video; (2) dengan media dapat merangsang siswa untuk memecahkan masalah sehingga dapat menumbuhkan berpikir kritis.

. Beberapa penelitian pengembangan mutimedia banyak dilaksanakan. Salah satu penelitian telah dilaksanakan oleh Supatmo dan Anik Ghufron (2019) yang berjudul "Developing Learning Multimedia to Improve Critical Thinking in Mathematics at Class V of Elementary School". Hasil penelitian menunjukkan bahwa kualitas produk mutimedia berbasis komputer untuk pembelajaran matematika siswa kelas V SD dalam hal aspek pembelajaran, aspek materi, aspek media dan persentase siswa yang mencapai ketuntasan belajar. Hasil penelitian menunjukkan bahwa hasil belajar menggunakan multimedia termasuk dalam kategori "sangat baik". Persentase siswa yang mencapai ketuntasan belajar setelah menggunakan multimedia pembelajaran sebanyak $77 \%$ dan termasuk dalam kategori "baik". Dengan demikian, produk multimedia tersebut sudah layak digunakan dalam pembelajaran matematika.

Berdasarkan latar belakang di atas, peneliti ingin mengembangkan multimedia lectora inspire yang mudah di aplikasikan dalam proses pembelajaran jarak jauh. Melalui multimedia lectora inspire diharapkan diperoleh suatu produk yang valid, praktis, dan efektif dalam penggunaannya serta dapat meningkatkan kemampuan berpikir siswa dalam menyelesaikan soal cerita materi bangun ruang.

Spesifikasi produk yang dihasilkan yang berupa multimedia lectora inspire adalah sebagai 
berikut: (1) multimedia lectora inspire berbentuk slide dengan tampilan yang menarik dan interaktif dengan adanya teks, foto, gambar, animasi, audio dan video juga terdapat kontrol navigasi yang berupa tombol pilihan menu; (2) menu utama dalam multimedia yang dihasilkan terdiri atas, sampul atau halaman depan, kompetensi, materi ajar, evaluasi, pustaka dan profil pengembang; (3) jenis tulisan yang digunakan adalah arial dengan ukuran font 12 pts; (4) gambar, foto, audio, dan video yang digunakan dalam multimedia berasal dari website google dan youtube; (5) latar belakang media didominasi dengan warna hijau dan biru muda; (6) materi yang digunakan merupakan materi bangun ruang mata pelajaran matematika kelas V SD berdasarkan kurikulum 2013 revisi 2017; (7) format multimedia aplikasi lectora inspire dikemas dalam format exe.

\section{METODE}

Jenis penelitian ini adalah penelitian dan pengembangan (R\&D). Penelitian ini bertujuan untuk mengembangkan produk yang divalidasi oleh beberapa tim ahli dan selanjutnya diujicobakan. Model pengembangan yang digunakan dalam penelitian ini adalah model DDDE dari Keren S. Ivers, Ann E. Barron (2002: 23). Alasan peneliti menggunakan model ini dikarenakan model DDDE cocok untuk mengembangkan produk multimedia, selain itu memiliki langkah kerja yang sistematik yakni pada setiap tahapan selalu mengacu pada langkah sebelumnya yang sudah diperbaiki sehingga diperoleh produk yang baik. Model Pengembangan DDDE terdiri atas empat tahap pengembangan, yaitu decide, design, development, dan evaluation. Keempat tahapan pengembangan tersebut dilakukan secara berurutan dan berkesinambungan. Subjek penelitian ini adalah peserta didik kelas V SDN Wonokusumo VI/45 Surabaya sebanyak 36 anak. Instrumen pengumpulan data terdiri dari angket validasi media, angket respon siswa, dan tes kemampuan berpikir kritis. Teknik analisis data berupa analisis kevalidan, analisis kepraktisan, dan analisis keefektifan.

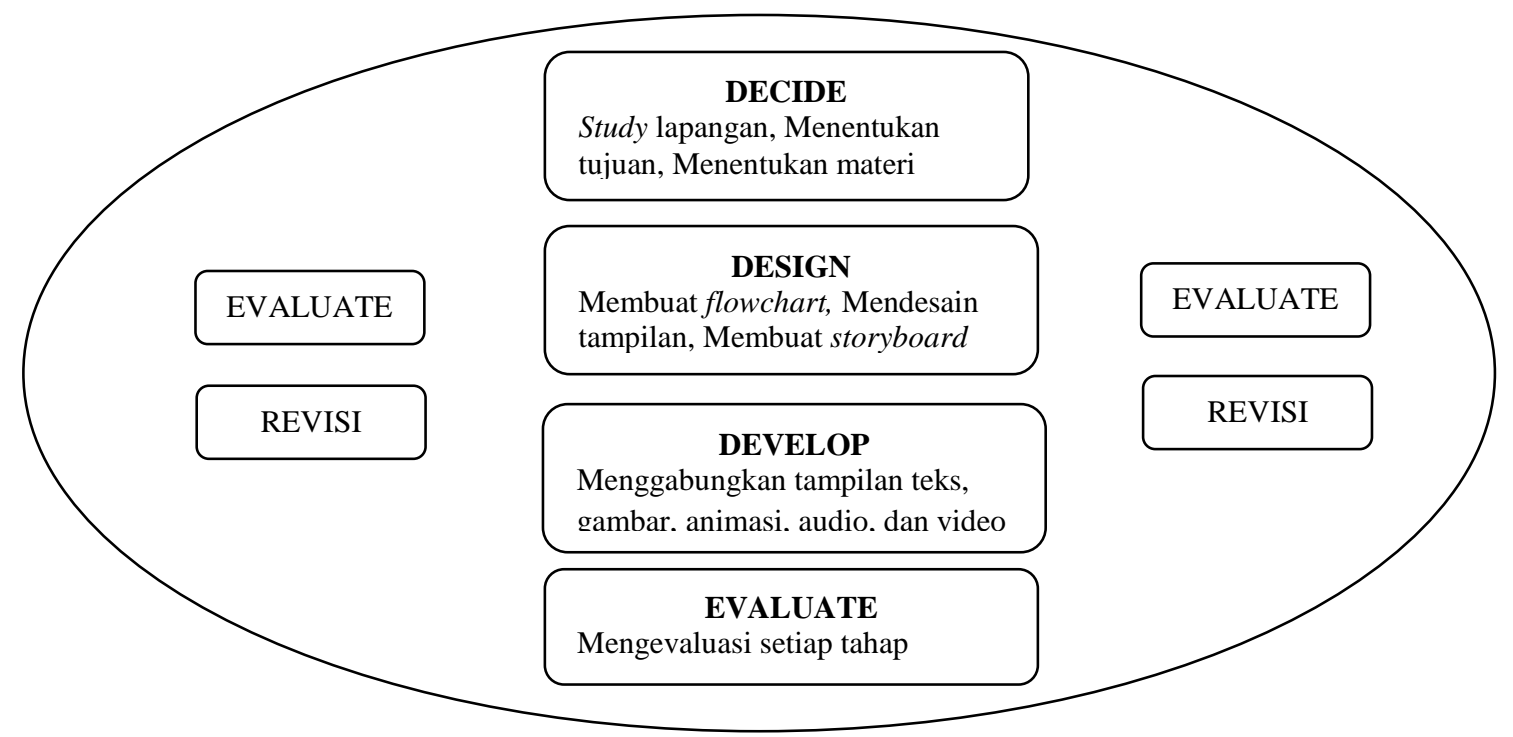

Bagan 1. Tahapan Model DDDE 


\section{HASIL}

Pengembangan multimedia lectora inspire pada materi bangun ruang kubus dan balok menggunakan model pengembangan DDDE yang terdiri atas empat tahap pengembangan, yaitu decide, design, development, dan evaluation. Keempat langkah atau tahap pengembangan tersebut dilakukan secara berurutan dan menyeluruh. Berikut uraian dari setiap fase.

\section{Decide (Pengambilan keputusan)}

Proses pengambilan keputusan membutuhkan beberapa analisis sebagai pertimbangan, mereka melakukan analisis kebutuhan, mengumpulkan sumber daya dan mengumpulkan ide. Dalam melakukan analisis kebutuhan, peneliti mengamati tempat objek studi. Dimulai dengan mewawancarai siswa tentang itu multimedia yang digunakan dalam proses pembelajaran jarak jauh. Kemudian, para peneliti juga melakukan wawancara dengan guru kelas tentang pemahaman mereka tentang pembelajaran multimedia, pembelajaran multimedia yang biasanya mereka gunakan untuk menyampaikan materi, dan proses pembelajaran di kelas mereka. Setelah itu, para peneliti mencari informasi yang terkait dengan fasilitas dan infrastruktur yang berkaitan dengan multimedia pembelajaran yang disediakan oleh sekolah. Yang terakhir, peneliti merumuskan tujuan dan pencapaian layak yang dapat mereka temukan atau siswa dapat capai setelah proses pembelajaran. Di sisi lain, proses pengumpulan sumber daya dilakukan untuk mengumpulkan semua alat yang diperlukan untuk mengembangkan multimedia lectora inspire. Untuk mengumpulkan ide, para peneliti mendiskusikan dan bertukar pikiran untuk menciptakan ide-ide kreatif dalam mengembangkan multimedia, sambil mengaitkan ide-ide tersebut dengan hasil analisis dan alat yang tersedia yang telah mereka kumpulkan sebelumnya.

\section{Design (Perancangan)}

Proses ini melibatkan: (a) Membuat flowcart untuk mengumpulkan semua bahan untuk produk; (b) Membuat storyboard dalam bentuk tertulis yang meliputi perencanaan, menulis storyboard dan tampilan, efek, grafik, musik, dan video; (c) Membuat perencanaan pengembangan, termasuk perencanaan narasi, efek visual, dan musik dalam video. Penyusunan instrumen yang akan digunakan untuk mengevaluasi kualitas multimedia pembelajaran yang telah dibuat dan kemampuan berpikir kritis peserta didik dalam menyelesaikan soal cerita bangun ruang setelah menggunakan media pembelajaran.

\section{Develop (Pengembangan)}

Pada tahap ini, peneliti mengembangkan rancangan media pembelajaran yang telah dibuat. Dalam pembuatan multimedia lectora inspire dengan menggunakan komputer atau PC, sebelumnya harus mengunduh dan menginstal dulu software melalui www.trivantis.com. Kemudian baru proses pembuatan multimedia dengan bahan-bahan dan materi yang telah direncanakan. Berikut ini merupakan isi dari media pembelajaran yang dikembangkan. 
Multimedia lectora inspire yang dikembangkan dimulai dari halaman depan. Pada halaman depan terdiri dari judul, menu masuk, kelas, dan nama pengembang. Tampilan halaman depan dapat dilihat seperti pada gambar 1 .

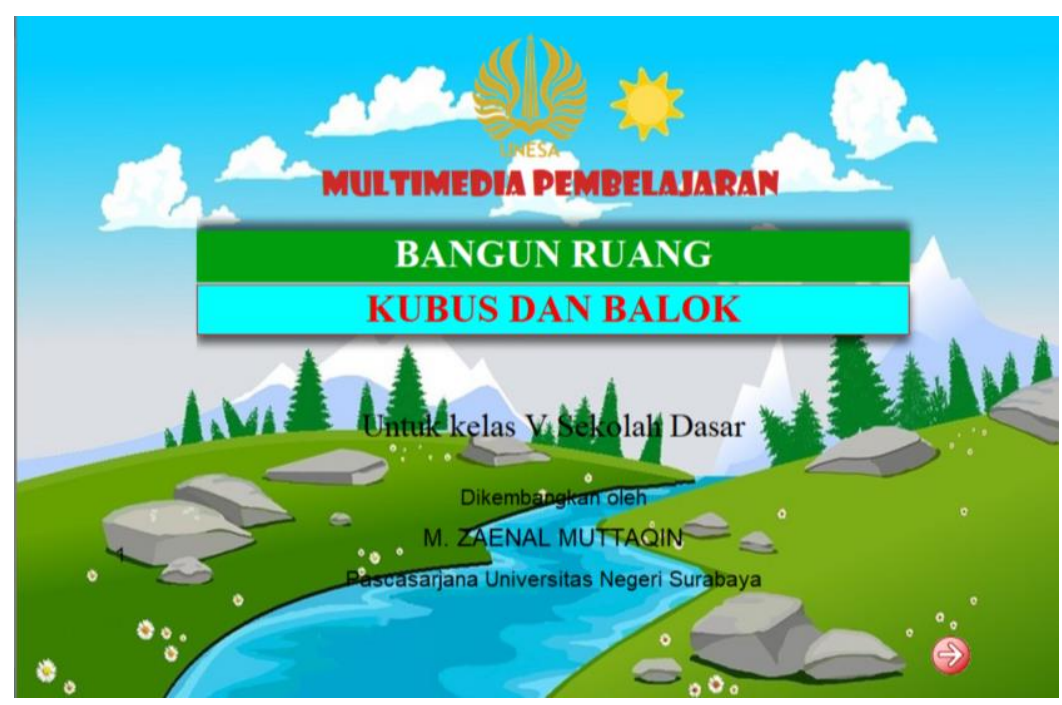

Gambar 1. Tampilan Bagian Pembuka

\section{Menu utama multimedia}

Menu utama multimedia ini merupakan bagian pokok dalam media pembelajaran. Semua bagianbagian media pembelajaran dapat diakses melalui menu utama ini. Pada bagian menu utama multimedia, terdapat beberapa pilihan yang bisa dipilih seperti kompetensi, materi, evaluasi, profil penyusun dan pustaka. Tampilan menu utama dapat dilihat pada Gambar 2.

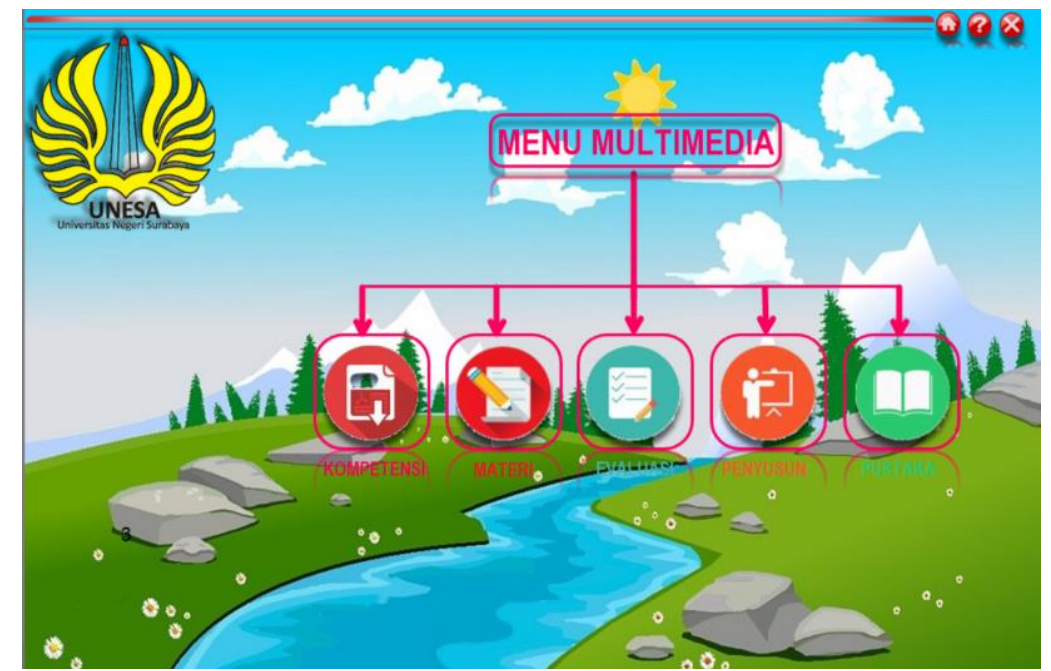

Gambar 2. Tampilan Menu Utama Multimedia

Bagian petunjuk penggunaan

Tampilan petunjuk penggunaan terdiri dari penjelasan singkat tentang isi media pembelajaran dan penjelasan tentang petunjuk penggunaan multimedia ini dapat dilihat pada gambar 3 . 
Pengembangan Multimedia Lectora Inspire Untuk Meningkatkan Kemampuan Berpikir Kritis Dalam Menyelesaikan Soal Cerita Bangun Ruang, M. Zaenal Muttaqin, Tatag Yuli Eko Siswono, Agung Lukito

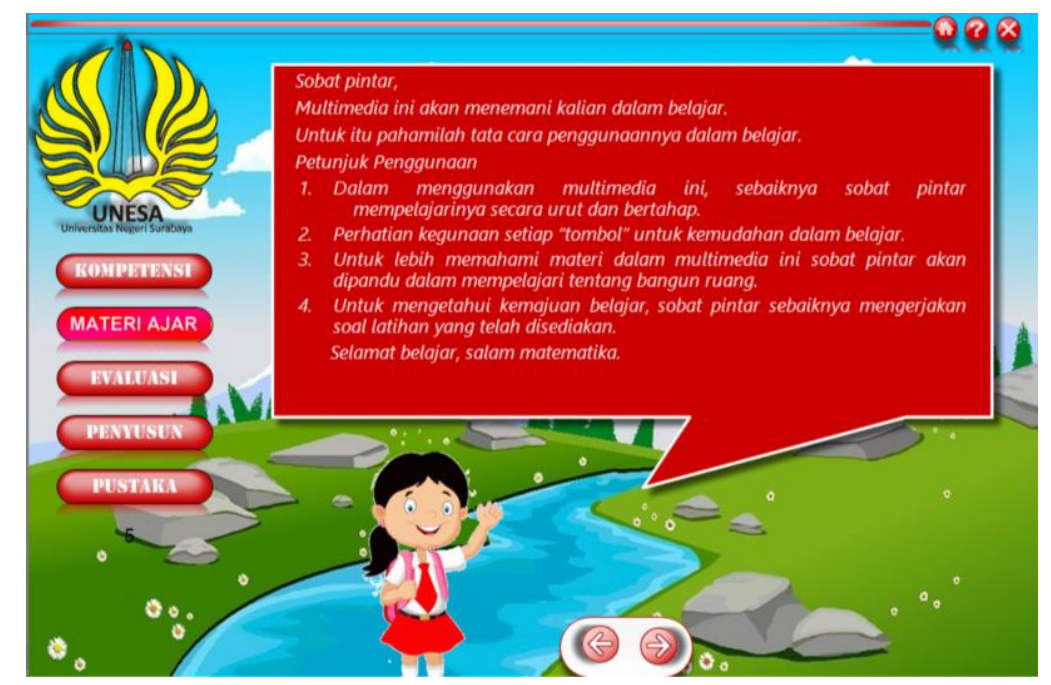

Gambar 3. Petunjuk Penggunaan

\section{Bagian kompetensi}

Tampilan bagian kompetensi terdapat tiga pilihan yaitu tujuan pembelajaran, kompetensi dasar dan kompetensi inti. Berikut tampilan kompetensi dalam multimedia ini dapat dilihat pada Gambar 4.

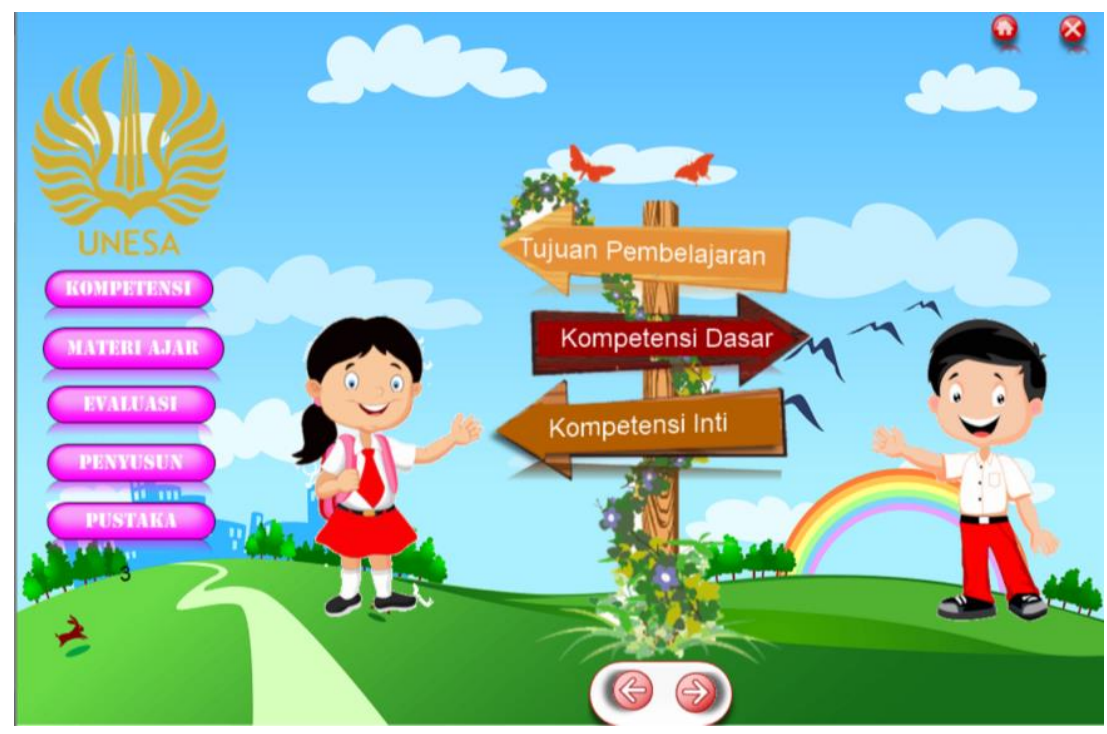

Gambar 4. Bagian kompetensi

Bagian materi ajar

Pada tampilan bagian materi ajar terdapat penjelasan konsep tentang bangun ruang yang berupa teks, gambar dan video serta contoh soal cerita yang berisi pemecahan masalah tentang bangun ruang. Adapun tampilan materi ajar dalam multimedia ini dapat dilihat pada Gambar 5. 


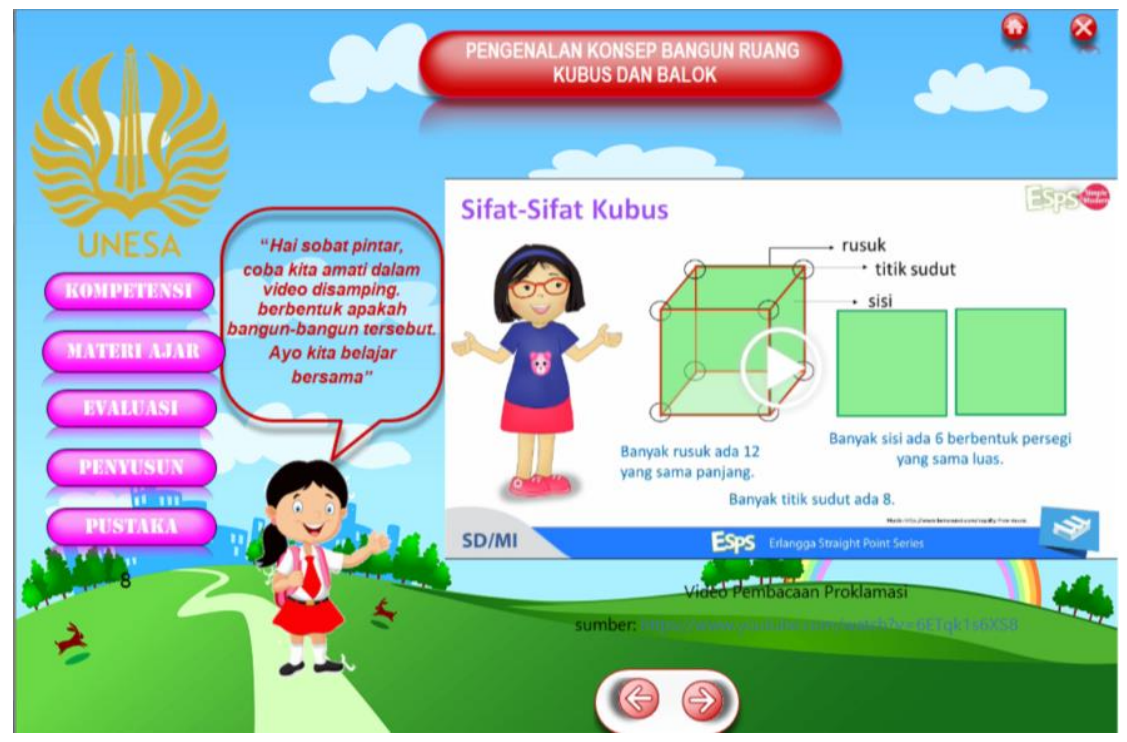

Gambar 5. Materi ajar

\section{Bagian evaluasi}

Pada bagian evaluasi terdapat tiga pilihan bentuk soal yang harus dikerjakan oleh siswa yaitu soal pilihan ganda, soal bergambar dan soal cerita atau uraian. Adapun tampilan bagian evaluasi pada multimedia ini dapat dilihat seperti gambar 6.

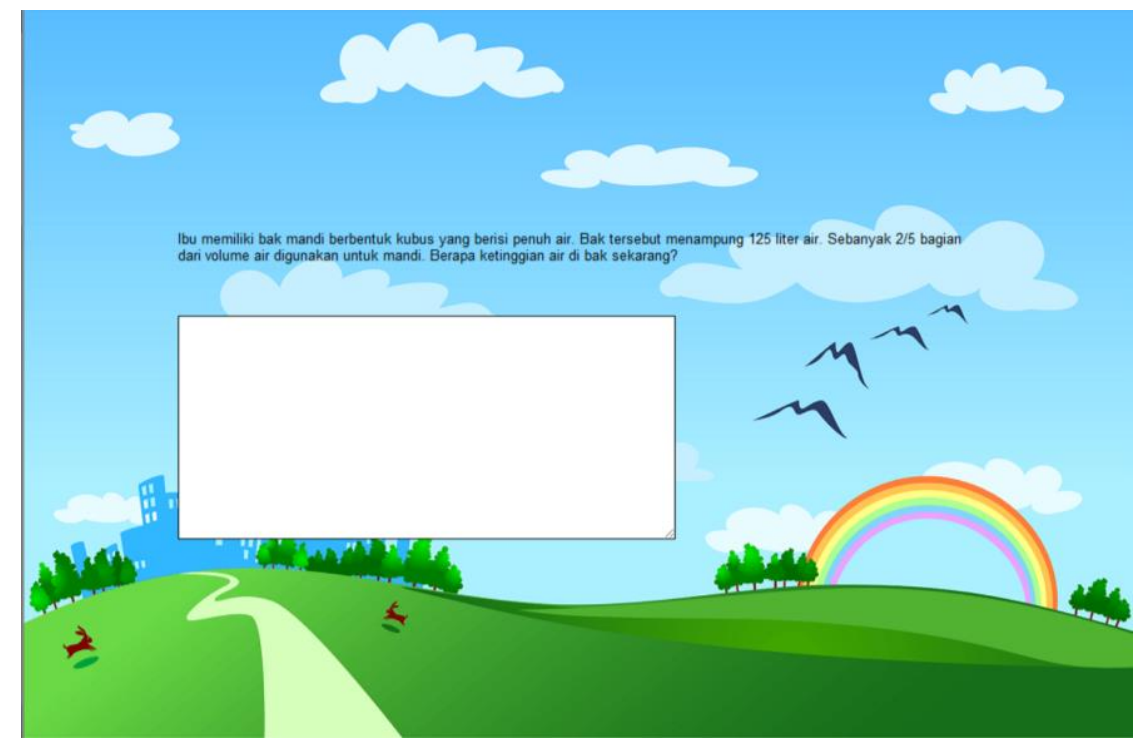

Gambar 6. Bagian evaluasi

\section{Bagian profil pengembang multimedia}

Pada bagian profil penyusun terdiri dari data personal dan kontak. Data personal diantaranya foto, nama, serta kampus pendidikan dari pengembang media pembelajaran. Kontak yang ditulis terdiri dari nomor handphone, email, dan kota pengembang. Adapun tampilan bagian profil penyusun pada multimedia ini dapat dilihat seperti gambar 7. 


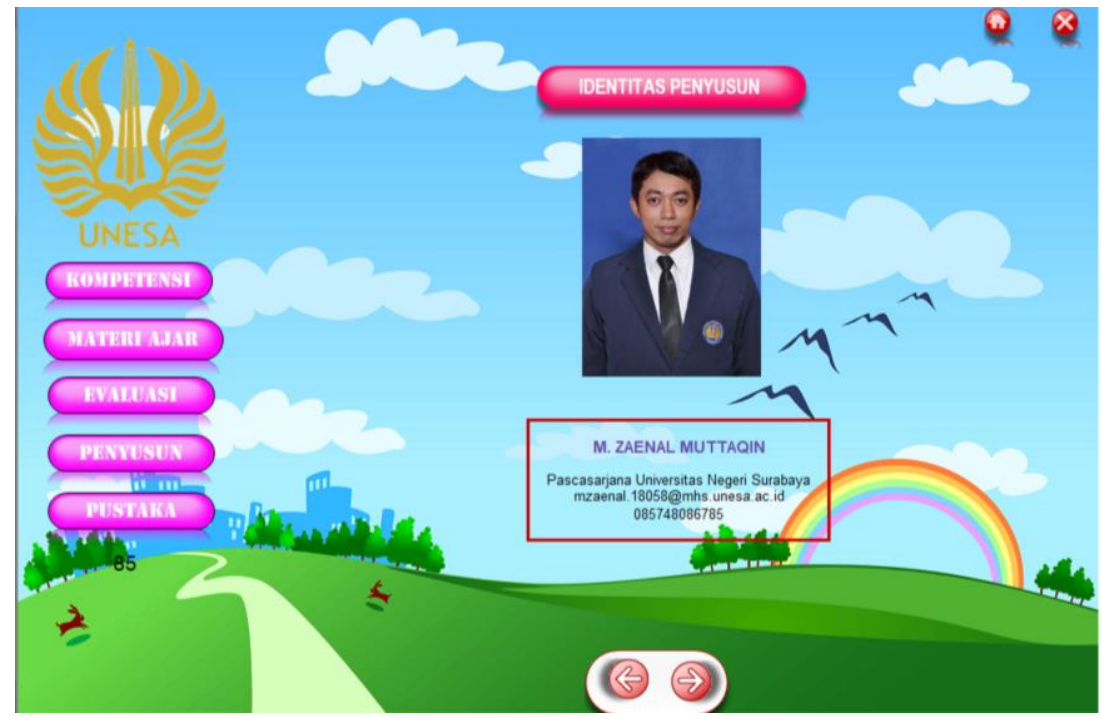

Gambar 7. Profil pengembang multimeda

\section{Bagian Pustaka}

Pada bagian Pustaka, terdapat referensi dan sumber tentang materi, gambar, dan video yang terkandung dalam multimedia lectora inspire ini. Adapaun tampilan bagian Pustaka dapat dilihat seperti pada gambar 8 .

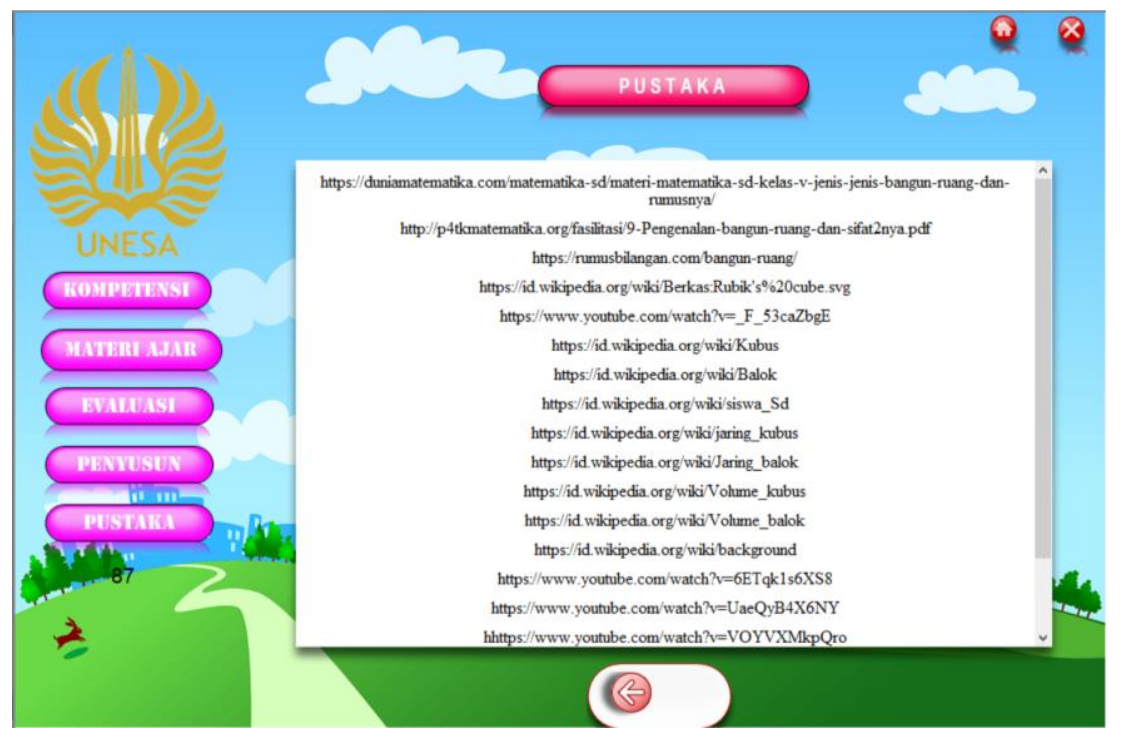

Gambar 8. Bagian Pustaka

\section{Hasil penilaian validitas multimedia}

Produk multimedia yang telah dikembangkan selanjutnya divalidasi oleh ahli materi dan ahli media. Data yang diperoleh dari penilaian ahli kemudian dihitung berdasarkan kriteria dalam pengembangan media.

Hasil penilaian ahli media untuk aspek tampilan dan pemograman setelah dihitung memperoleh persentase $82.50 \%$. Nilai ini kemudian dikonversi dan diperoleh bahwa penilaian kevalidan multimedia berdasarkan penilaian dari ahli media termasuk dalam kategori baik. Adapun hasil penilaian ahli materi, media dinilai dari aspek kualitas isi/materi mendapatkan persentase 80,64 yang 
termasuk dalam kategori baik. Kelayakan multimedia lectora inspire setelah dihitung rata-rata dari persentase dari ahli media dan ahli materi memperoleh persentase $81,57 \%$. Nilai ini kemudian dikonversi diperoleh bahwa penilaian kevalidan multimedia berdasarkan penilaian dari ahli materi termasuk dalam kategori sangat baik. Dengan demikian, multimedia lectora inspire ini dinilai valid sehingga dapat dinyatakan layak digunakan sebagai media pembelajaran.

Hasil validasi RPP terdapat $73 \%$ hingga $80 \%$ termasuk kriteria sangat baik, 20\% hingga 27\% yang tergolong pada kriteria baik. Berdasarkan kriteria minimal baik, maka RPP dikatakan valid. Dengan demikian dapat disimpulkan bahwa RPP telah valid dan layak digunakan untuk penelitian.

Hasil validasi LKPD terdapat 56\% termasuk kriteria sangat baik, $44 \%$ yang tergolong pada kriteria baik. Berdasarkan kriteria minimal baik, maka instrumen LKPD ini dapat dikatakan valid dan layak digunakan untuk penelitian.

Tes Hasil Belajar yang telah dikembangkan telah divalidasi dan memenuhi kriteria minimal baik (skor 3). Maka dapat disimpulkan bahwa THB telah valid dan layak digunakan untuk penelitian. Tes berpikir kritis yang telah dikembangkan telah memenuhi kriteria minimal baik (skor 3). Maka dapat disimpulkan bahwa tes berpikir kreatif ini valid dan layak digunakan untuk penelitian.

Hasil validasi angket respon siswa dari 10 aspek yang dinilai. Terdapat 8 aspek mendapatkan skor 4 (80\% sangat baik) dan 2 aspek mendapatkan skor 3 (20\% baik). Berdasarkan kriteria minimal baik, maka instrumen ini valid dan layak digunakan untuk penelitian.

\section{Hasil penilaian kepraktisan multimedia}

Setelah dihasilkan multimedia dan perangkat serta merevisi sehingga menjadi draft final yang layak selanjutnya dilakukan uji coba perorangan (one to one trial). Uji coba ini dilakukan dengan memberikan angket lembar penilaian kepraktisan media kepada seorang guru kelas dan 6 siswa di SDN Wonokusumo VI/45 Surabaya. Berdasarkan analisis data hasil lembar penilaian kepraktisan oleh guru ada 16 aspek yang dinilai. Terdapat 12 aspek mendapatkan skor 4 (75\% sangat baik) dan 4 aspek mendapatkan skor 3 (19\% baik). Berdasarkan kriteria kelayakan pada media dengan kategori minimal baik (skor 3), maka dapat disimpulkan bahwa multimedia lectora inspire dikatakan praktis dan mudah untuk digunakan guru dalam proses pembelajaran. Sedangkan hasil lembar penilaian kepraktisan oleh 6 siswa secara keseluruhan, terdapat 70\% - 90\% (kriteria sangat baik), 10\% - 30\% (kriteria baik). Berdasarkan kriteria kepraktisan pada media dengan kategori minimal baik (skor 3), maka dapat disimpulkan bahwa multimedia lectora inspire dikatakan praktis dan mudah untuk digunakan siswa dalam pembelajaran.

Setelah multimedia diuji coba secara perorangan kemudian dilakukan Uji Coba Kelompok Kecil (small group trial) dengan memberikan angket respon, tes berpikir kritis, dan tes hasil belajar. Respon siswa dari 10 butir pertanyaan yang diajukan mendapatkan presentase di atas $75 \%$ yaitu sebesar $85,50 \%$, sehingga menurut kriteria yang ditetapkan, maka dapat disimpulkan bahwa respon 
siswa terhadap pembelajaran menggunakan multimedia lectora inspire dalam menyelesaikan soal cerita materi bangun ruang adalah positif.

Selanjutnya untuk mengukur peningkatan kemampuan berpikir kritis pada tahap uji coba kelompok kecil dan kelompok besar dilihat berdasarkan indikator berpikir kritis yaitu menginterpretasi, menganalisis, mengevaluasi, dan menginferensi. Setiap indikator memiliki nilai skor antara 1 sampai 4. Sehingga didapatkan nilai total skor maksimal 16. Adapun cara perhitungan nilai persentase adalah sebagai berikut :

Nilai Persentase $=\frac{\text { Skor Perolehan }}{\text { Skor Maksimal }} \times 100 \%$

Nilai persentase kemampuan berpikir kritis yang diperoleh dari perhitungan kemudian di kategorikan sesuai dengan tabel berikut ini:

Tabel 1.

Kategori Persentase Kemampuan Berpikir Kritis

\begin{tabular}{|c|c|}
\hline Persentase (\%) & Kategori \\
\hline $81,25<\mathrm{X} \leq 100$ & Sangat tinggi \\
\hline $71,5<\mathrm{X} \leq 81,25$ & Tinggi \\
\hline $62,5<\mathrm{X} \leq 71,5$ & Sedang \\
\hline $43,75<\mathrm{X} \leq 62,5$ & Rendah \\
\hline $0<\mathrm{X} \leq 43,75$ & Sangat rendah \\
\hline
\end{tabular}

Selanjutnya jumlah tiap kategori dalam satu kelas di analisis dan di kelompokkan berdasarkan pretest dan post-test dimasukkan dalam tabel berikut.

\section{Tabel 2.}

Hasil Tes Berpikir Kritis pada Tahap Uji Coba Kelompok Kecil

\begin{tabular}{|c|l|c|c|c|c|}
\hline \multirow{2}{*}{ No. } & \multirow{2}{*}{$\begin{array}{c}\text { Tingkat Kemampuan } \\
\text { Berpikir Kritis }\end{array}$} & \multicolumn{2}{|c|}{ Pre Test } & \multicolumn{2}{c|}{ Post Test } \\
\cline { 3 - 6 } & Banyak Siswa & Persentase & Banyak Siswa & Persentase \\
\hline 1 & Sangat Tinggi & 0 & $0 \%$ & 6 & $16,6 \%$ \\
\hline 2 & Tinggi & 5 & $13,8 \%$ & 13 & $36,1 \%$ \\
\hline 3 & Sedang & 14 & $38,8 \%$ & 10 & $27,7 \%$ \\
\hline 4 & Rendah & 9 & $25 \%$ & 5 & $13,8 \%$ \\
\hline 5 & Sangat Rendah & 8 & $22,2 \%$ & 2 & $5,5 \%$ \\
\hline \multicolumn{2}{r|}{ Jumlah } & 36 & $100 \%$ & 36 & $100 \%$ \\
\hline
\end{tabular}

Berdasarkan tabel 2 dapat direpresentasikan skema perubahan tingkat kemampuan berpikir kritis siswa sebelum pembelajaran menggunakan multimedia lectora inspire (pre-test) dan setelah pembelajaran menggunakan multimedia lectora inspire (post-test), sebagai berikut: 


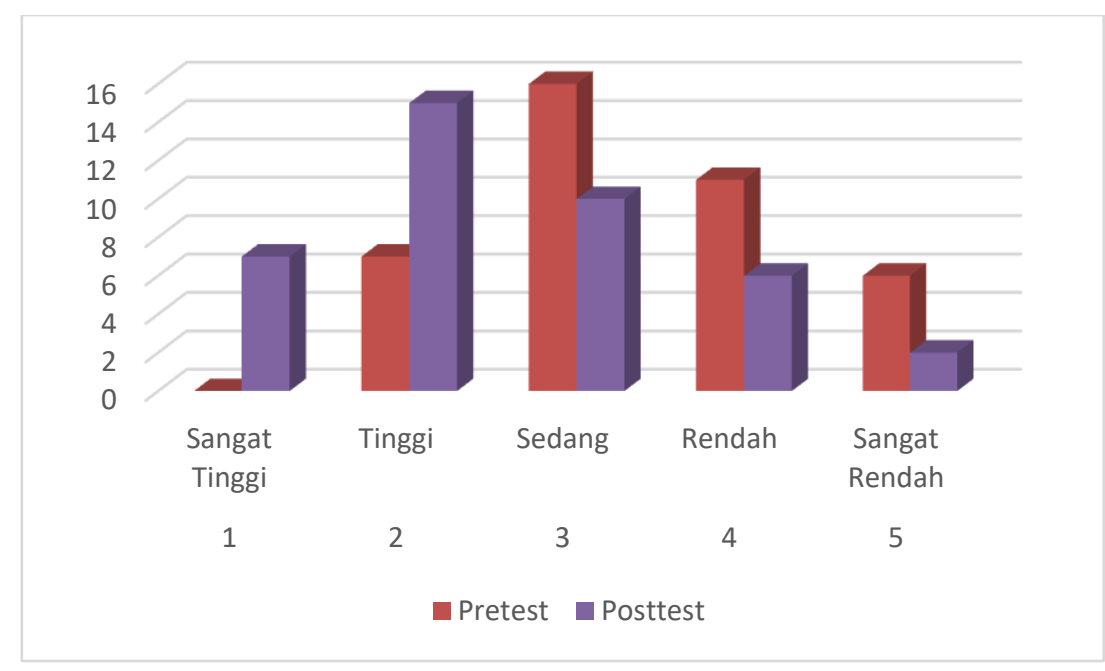

Gambar 9. Grafik kemampuan berpikir kritis siswa pada tahap uji coba kelompok kecil

Dari grafik di atas menunjukkan bahwa siswa mengalami peningkatan pada tingkat kemampuan berpikir kritis siswa setelah diterapkan pembelajaran menggunakan multimedia lectora inspire. Persentase peningkatan kemampuan berpikir kritis siswa pada tahap uji coba kelompok kecil sebesar $80 \%$.

Dengan demikian, berdasarkan hasil persentase perubahan tingkat kemampuan berpikir kritis siswa pada tahap uji coba kelompok kecil setelah pembelajaran menggunakan multimedia lectora inspire dapat dikatakan positif karena $\geq 75 \%$ (Afiani, 2015).

Selanjutnya data tentang tes hasil belajar dimulai dengan menguji validitas dan reliabilitas butir soal, dan hasil THB. Dapat dipaparkan hasil tentang validitas dan reliabilitas butir soal tes hasil belajar pada tabel berikut ini.

\section{Tabel 3.}

Hasil Uji Validitas Butir Soal pada Tahap Uji Coba Kelompok Kecil

\begin{tabular}{ccccc}
\hline Butir Soal & $\begin{array}{c}\mathbf{r}_{\text {tabel }} \\
(\mathbf{N = 3 6 )}\end{array}$ & $\begin{array}{c}\mathbf{r}_{\text {hitung }} \\
\left(\mathbf{r}_{\mathbf{x y}}\right)\end{array}$ & Kriteria & Keterangan \\
\hline No. 1 & 0,329 & 0,690 & Sedang & Valid \\
\hline No. 2 & 0,329 & 0,543 & Sedang & Valid \\
\hline No. 3 & 0,329 & 0,439 & Sedang & Valid \\
\hline No. 4 & 0,329 & 0,770 & Tinggi & Valid \\
\hline No. 5 & 0,329 & 0,817 & Tinggi & Valid \\
\hline No. 6 & 0,329 & 0,690 & Sedang & Valid \\
\hline No. 7 & 0,329 & 0,543 & Sedang & Valid \\
\hline No. 8 & 0,329 & 0,439 & Sedang & Valid \\
\hline No. 9 & 0,329 & 0,770 & Tinggi & Valid \\
\hline No. 10 & 0,329 & 0,817 & Tinggi & Valid \\
\hline & & & Sumber: Data olahan peneliti, 2020
\end{tabular}

Hasil $r_{\text {hitung }}$ pada butir soal nomor 4,5,9, dan 10 termasuk dalam kriteria 
tinggi. Karena butir soal nomor 1 sampai 10 diperoleh $r_{\text {hitung }}>r_{\text {tabel }}$, maka dapat disimpulkan bahwa setiap butir soal telah valid. Selanjutnya hasil reliabilitas butir soal THB dapat dilihat pada tabel 4 berikut ini.

Tabel 4.

Hasil Uji Reliabilitas Butir Soal pada Tahap Uji Coba Kelompok Kecil

\begin{tabular}{cclc}
\hline $\begin{array}{c}\mathbf{r}_{\text {tabel }} \\
(\mathbf{N}=\mathbf{3 6})\end{array}$ & $\begin{array}{c}\text { Reliabilitas Butir } \\
\text { Soal }\end{array}$ & Kriteria & Keterangan \\
\hline 0,329 & 0,840 & Tinggi & Reliabel \\
\hline & & Sumber: Data olahan peneliti, 2020
\end{tabular}

Hasil uji reliabilitas butir soal menunjukkan reliabilitas sebesar 0,840 termasuk pada kriteria tinggi. Dikarenakan nilai reliabilitas butir soal lebih besar daripada $\mathrm{r}_{\text {tabel}}$, maka dapat disimpulkan bahwa butir soal telah reliabel. Sesuai dengan tabel hasil THB, ketuntasan belajar secara klasikal dapat dihitung seperti berikut:

$$
\begin{aligned}
\text { Persentase Ketuntasan Klasikal } & =\frac{\text { Jumlah siswa yang tuntas }}{\text { Jumlah siswa yang mengikuti tes }} \times 100 \% \\
& =\frac{31}{36} \times 100 \% \\
& =86 \%
\end{aligned}
$$

Berdasarkan penghitungan ketuntasan klasikal di atas, maka persentase ketuntasan belajar secara klasikal dapat dikatakan tuntas. Selanjutnya media yang sudah dikembangkan dan diujicobakan pada kelas kecil lalu akan diujicobakan dalam kelas besar yaitu ada 40 siswa dalam satu kelas yang akan diberikan angket respon, THB, dan tes berpikir kritis. Respon siswa pada tahap implementasi dari 10 butir pertanyaan yang diajukan memperoleh hasil rata-rata di atas $75 \%$ yaitu sebesar $86 \%$, sehingga menurut kriteria minimal baik, maka dapat disimpulkan bahwa respon siswa terhadap pembelajaran menggunakan multimedia lectora inspire pada materi bangun ruang adalah positif. Data hasil tes kemampuan berpikir kritis siswa dapat disajikan pada tabel berikut ini.

\section{Tabel 5.}

Hasil Tes Berpikir Kritis pada tahap uji coba kelompok besar

\begin{tabular}{|c|l|c|c|c|c|}
\hline \multirow{2}{*}{ No. } & \multirow{2}{*}{$\begin{array}{c}\text { Tingkat Kemampuan } \\
\text { Berpikir Kritis }\end{array}$} & \multicolumn{2}{|c|}{ Pre Test } & \multicolumn{2}{c|}{ Post Test } \\
\cline { 3 - 6 } & Banyak Siswa & Persentase & Banyak Siswa & Persentase \\
\hline 1 & Sangat Tinggi & 0 & $0 \%$ & 7 & $15,5 \%$ \\
\hline 2 & Tinggi & 7 & $17,5 \%$ & 15 & $37,5 \%$ \\
\hline 3 & Sedang & 16 & $40,0 \%$ & 10 & $15,0 \%$ \\
\hline 4 & Rendah & 11 & $27,5 \%$ & 6 & $15,0 \%$ \\
\hline 5 & Sangat Rendah & 6 & $15,0 \%$ & 2 & $5,0 \%$ \\
\hline \multicolumn{2}{r|}{ Jumlah } & 40 & $100 \%$ & 40 & $100 \%$ \\
\hline
\end{tabular}


Berdasarkan tabel di atas dapat direpresentasikan skema perubahan tingkat kemampuan berpikir siswa sebelum pembelajaran menggunakan media cerita bergambar (pre-test) dan setelah pembelajaran menggunakan media cerita bergambar (post-test), sebagai berikut.

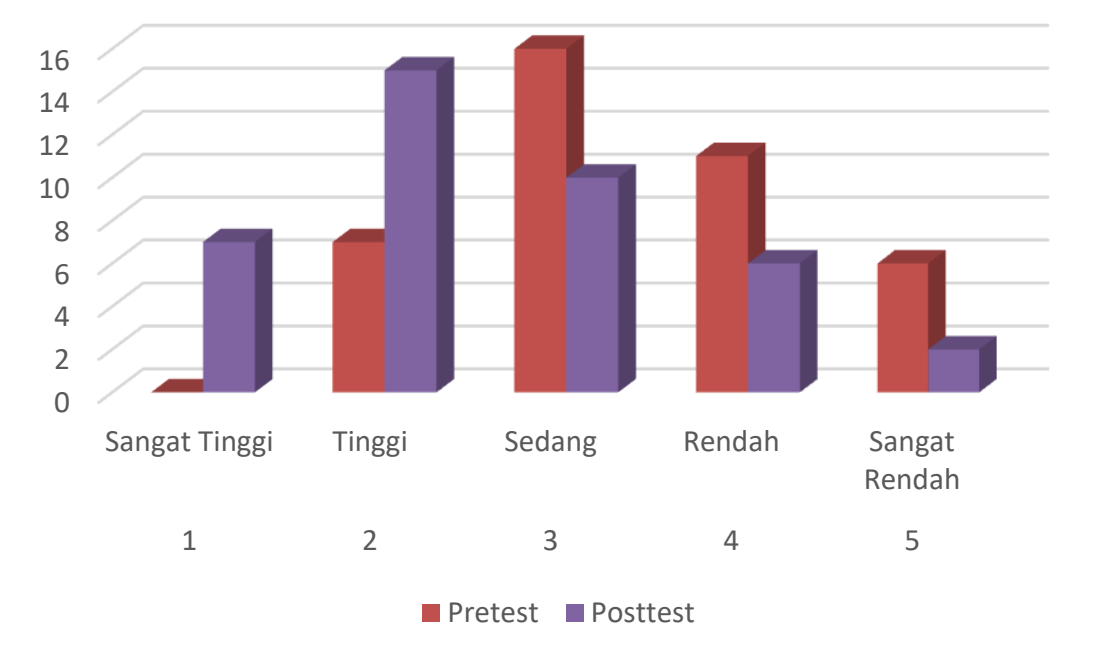

Gambar 8. Grafik kemampuan berpikir kreatif siswa pada tahap implementasi

Dari grafik di atas menunjukkan bahwa siswa mengalami peningkatan pada tingkat kemampuan berpikir kritis setelah diterapkan pembelajaran menggunakan multimedia inspire. Persentase peningkatan tingkat kemampuan berpikir kritis pada tahap uji coba kelas besar telah mengalami peningkatan sebesar $85 \%$.

Dengan demikian, berdasarkan hasil persentase perubahan tingkat kemampuan berpikir kritis siswa pada tahap uji coba kelas besar setelah pembelajaran menggunakan media cerita bergambar dapat dikatakan positif karena $\geq 75 \%$. Selanjutnya data tes hasil belajar pada tahap uji coba kelas besar dapat dijelaskan melalui Tabel 6 berikut ini.

\section{Tabel 6.}

Hasil Uji Validitas Butir soal pada tahap uji coba kelas besar

\begin{tabular}{ccccc}
\hline Butir Soal & $\begin{array}{c}\mathbf{r}_{\text {tabel }} \\
(\mathbf{N = 4 0 )}\end{array}$ & $\begin{array}{c}\mathbf{r}_{\text {hitung }} \\
\left(\mathbf{r}_{\text {xy }}\right)\end{array}$ & Kriteria & Keterangan \\
\hline No. 1 & 0,316 & 0,690 & Sedang & Valid \\
\hline No. 2 & 0,316 & 0,543 & Sedang & Valid \\
\hline No. 3 & 0,316 & 0,439 & Sedang & Valid \\
\hline No. 4 & 0,316 & 0,770 & Tinggi & Valid \\
\hline No. 5 & 0,316 & 0,817 & Tinggi & Valid \\
\hline No. 6 & 0,316 & 0,690 & Sedang & Valid \\
\hline No. 7 & 0,316 & 0,543 & Sedang & Valid \\
\hline No. 8 & 0,316 & 0,439 & Sedang & Valid \\
\hline No. 9 & 0,316 & 0,770 & Tinggi & Valid \\
\hline No. 10 & 0,316 & 0,817 & Tinggi & Valid \\
\hline
\end{tabular}

Sumber: Data olahan peneliti, 2020

Berdasarkan hasil uji validitas butir soal pada tabel 4, dari 10 butir soal yang diujikan. Karena butir soal nomor 1 sampai nomor 10. diperoleh $\mathrm{r}_{\text {hitung }}>\mathrm{r}_{\text {tabel }}$, maka dapat disimpulkan bahwa setiap butir 
soal dapat dinyatakan valid. Selanjutnya dihitung reliabilitas butir soal yang dapat disajikan pada tabel 7 berikut ini.

\section{Tabel 7.}

Hasil uji reliabilitas butir soal pada tahap uji coba kelas besar

\begin{tabular}{cccc}
\hline $\begin{array}{c}\mathbf{r}_{\text {tabel }} \\
(\mathrm{N}=40)\end{array}$ & Reliabilitas Butir Soal & Kriteria & Keterangan \\
\cline { 1 - 1 } 0,312 & 0,620 & Tinggi & Reliabel \\
\hline
\end{tabular}

Sumber: Data olahan peneliti, 2020

Hasil uji reliabilitas butir soal menunjukkan reliabilitas sebesar 0,840 termasuk pada kriteria tinggi. Dikarenakan nilai reliabilitas butir soal lebih besar daripada $r_{\text {tabel }}$, maka dapat disimpulkan bahwa butir soal telah reliabel. Sesuai dengan tabel hasil THB, ketuntasan belajar secara klasikal dapat dihitung seperti berikut:

$$
\begin{aligned}
\text { Persentase Ketuntasan Klasikal } & =\frac{\text { Jumlah siswa yang tuntas }}{\text { Jumlah siswa yang mengikuti tes }} \times 100 \% \\
& =\frac{35}{40} \times 100 \% \\
& =87,5 \%
\end{aligned}
$$

Berdasarkan penghitungan ketuntasan klasikal di atas, maka persentase ketuntasan belajar secara klasikal dapat dikatakan tuntas.

\section{Evaluate (Evaluasi)}

Tahap ini terdiri dari evaluaasi formatif dan sumatif. Evaluasi formatif dilaksanakan di akhir kegiatan pada setiap tahap penelitian. Evaluasi yang dimaksudkan untuk memperbaiki media di setiap tahap pengembangan. Masing-masing tahap dievaluasi dan direvisi untuk mendapatkan hasil media yang layak meliputi valid, praktis, dan efektif. Hasil evaluasi formatif telah dijabarkan pada tiap fase. Evaluasi sumatif diperoleh dari hasil data angket respon siswa pada tahap uji coba kelompok kecil mendapat hasil respon yaitu sebanyak $84,50 \%$, sedangkan pada tahap uji coba kelompok besar mendapat hasil respon $89 \%$. Dengan demikian, pembelajaran dengan menggunakan multimedia lectora inspire dikatakan positif pada tahap uji coba kelompok kecil maupun kelompok besar. Hasil penilaian tes hasil belajar pada tahap uji coba yang mencapai ketuntasan dengan nilai KKM 75 sebanyak 31 dari 36 siswa atau 86\% tingkat ketuntasan kelas, sedangkan pada tahap uji coba kelas besar yang mencapai ketuntasan dengan nilai KKM 75 sebanyak 37 dari 40 siswa atau 89\% tingkat ketuntasan kelas. Hasil dari tes berpikir kritis siswa yang menunjukkan perubahan positif pada tahap uji coba kelompok kecil sebesar $81 \%$, sedangkan pada tahap uji coba kelompok besar mendapat $84 \%$. Dengan demikian, dapat disimpulkan bahwa pembelajaran yang telah dilaksanakan dengan menggunakan multimedia lectora inspire adalah efektif. 


\section{KESIMPULAN}

Berdasarkan hasil penelitian dan pembahasan, maka dapat disimpulkan bahwa kelayakan multimedia lectora inspire dalam menyelesaikan soal cerita materi bangun ruang berdasarkan penilaian kevalidan, kepraktisan, dan keefektifan sebagai berikut: (1) Hasil penilaian validitas oleh ahli media dan ahli materi menunjukkan bahwa media pembelajaran yang dikembangkan memenuhi indeks kevalidan $\geq 62.50 \%$. Hasil validasi media sebesar $82.50 \%$ dan validasi materi/isi sebesar $80.64 \%$ dengan kategori baik. Dengan demikian, multimedia lectora inspire valid digunakan dalam pembelajaran matematika khususnya materi bangun ruang. (2) Hasil penilaian kepraktisan multimedia lectora inspire oleh peserta didik kelas V SDN Wonokusumo VI/45 menunjukkan bahwa media pembelajaran yang dikembangkan memenuhi indeks kepraktisan $\geq 62.50 \%$ dengan kategori baik. Dengan demikian, multimedia lectora inspire sangat praktis digunakan dalam pembelajaran matematika. (3) Hasil penilaian keefektifan dari hasil tes berpikir kritis mengalami perubahan positif ditandai dengan peningkatan yang signifikan. Kemampuan berpikir kreatif siswa pada tahap uji coba kelompok kecil mengalami kemajuan sebesar $81 \%$ dan pada tahap implementasi mengalami kemajuan sebesar $84 \%$. Sehingga dapat disimpulkan bahwa multimedia lectora inspire efektif untuk digunakan pada pembelajaran matematika.

Berdasarkan hasil penelitian dan pengembangan yang telah dilakukan, maka saran yang dapat diberikan meliputi: (1) multimedia lectora inspire dapat dijalankan menggunakan gadget atau android dengan syarat harus mengintsall aplikasi $s w f$ terlebih dahulu, sehingga lebih praktis penggunaannya; (2) pada penelitian ini, tes dan angket masih dilakukan menggunakan tes tulis. Ada kemungkinan tes dapat diintegrasikan secara online atau daring dengan menggunakan google form, Microsoft office form, dan atau program quiz; (3) multimedia lectora inspire dalam pembelejaran dapat digunakan sebagai media presentasi interaktif dan sekaligus latihan soal.

\section{DAFTAR PUSTAKA}

Facione, Peter A. (1990). Critical Thinking; A Statement of Expert Concensus for Purpose of Educational Assessment and Instruction. American Philosophical Association, Newark, Del.

Haryani, Desti. (2012). Membentuk Siswa Berpikir Kritis Melalui Pembelajaran Matematika. Yogyakarta: Seminar asional Matematika dan Pendidikan Matematika.

Ivers, Karen S dan Barron Ann E. 2002. Multimedia Project In Education: Designing, Producing and Assessing. United States of America: Libraries Unlimited

Jonassen, David. (2004). Designing Constructivist Learning Environments. Pennsylvania: Pennsylvania State University.

Munir. (2013). Multimedia Konsep \& Aplikasi dalam Pendidikan. Bandung: Alfabeta. 
Pengembangan Multimedia Lectora Inspire Untuk Meningkatkan Kemampuan Berpikir Kritis Dalam Menyelesaikan Soal Cerita Bangun Ruang, M. Zaenal Muttaqin, Tatag Yuli Eko Siswono, Agung Lukito

Priyanto, Arif. (2015). Analisis Kesalahan Siswa dalam Menyelesaikan Soal Cerita Matematika Pokok Bahasan Teorema Pythagoras Berdasarkan Kategori Kesalahan. Jember : Artikel Ilmiah Mahasiswa I (1) : 1-5.

Siswono, T. Y. E. (2018). Pembelajaran Matematika Berbasis Pengajuan Masalah dan Pemecahan Masalah. Bandung: PT Remaja Rosdakarya.

Supatmo and Anik Ghufron, (2019), Developing Learning Multimedia to Improve Critical Thinking in Mathematics at Class $V$ of Elementary School. International Conference on Meaningful Education, KnE Social Sciences, pages 17-26. DOI 10.18502/kss.v3i17.4619.

Wahyudin. (2016). Analisis Kemampuan Menyelesaikan Soal Cerita Matematika Ditinjau dari Kemampuan Verbal. Jurnal Universitas Muhammadiyah Makassar Vol. 9 No. 2 (Nopember) 2016, Hal. 148-160. 